\title{
Mitigation Strategies of Land Use for Zengwen Reservoir and Its Catchment: Post-Disaster of Typhoon Morakot
}

\author{
Miao-Yun Chen, I-Chang Chow \\ Feng Chia University, Ph.D. Program in Civil and Hydraulic Engineering, Taichung, Taiwan \\ Email: chowic@fcu.edu.tw
}

Received July 2014

\begin{abstract}
Mitigation and adaptation have become two main strategies that governments around the world are focusing on in response to the threat of global climate change. In August 2009, Typhoon Morakot heavily damaged the central and southern parts of Taiwan, causing irreversible damage to the environment, especially in the mountain areas. In this study, the goal is to attain sustainable reservoir management, thus comprehensive storm water management is used to develop mitigation strategies. Overlay-map methods of GIS, along with vulnerability analysis and land use sustainability analysis, are used to map out optimal land use patterns containing development potentials, growth limits, and suitability concerns that aim to reduce the impact of human development on the ecological environment. Finally, the mitigation strategies proposed by this study for the land use of Zengwen Reservoir and its catchment will be implement shortly.
\end{abstract}

\section{Keywords}

Global Climate Change, Environment Vulnerability, Sensitive Area, Suitability Analysis, Mitigation, Adaptation, Map Overlay, Comprehensive Storm Water Management, Catchment

\section{Introduction}

With the increasing consequences of global climate change (GCC) and the greenhouse effect, how humans adapt to these consequences, continue their lives, adjust in land use, social-economic development, and achieve a stable and balanced natural system are as equally important as mitigation. For this reason, both mitigation and adaptation have been major areas of focus in the government's response to the threat of climate change [1].

Central and southern Taiwan was badly hit by Typhoon Morakot in August 2009, which caused not only great loss of lives and properties, but also irreversible damage to the mountainous lands and the environment. The present study uses comprehensive storm water management as the core mitigation strategy. Through stable reservoir water supply recovery, water conservation, catchment protection, and adjustment of land use for existing living and production space, as well as analyzing the vulnerability indicator [2] [3] and land suitability analysis [4]-[6], the study explores the impact of current land use on water quality, quantity and water supply. In addition, 
the study also suggests land use adjustments [7] to reduce the impact of human development on the ecological environment of catchment area and eventually achieve the goal of sustainable reservoir management.

\section{Trend of Upstream Catchment Governance in Response to GCC}

\subsection{Impact and Response to GCC}

GCC increases the probability and intensity of extreme weather events, and causes more frequent floods and hillside disasters triggered by typhoons and rainstorms. Taiwan is vulnerable to typhoons and storms [8]. Its topographical and geological conditions make hillside disasters such as debris avalanche, mudslide, and landslide more frequent in Taiwan. Problems such as overuse, misuse of land resources caused by improper development in the past and dwindling permeable and storage area will cause severe damage when natural disasters occur. Furthermore, considerable destruction to infrastructure caused by the disasters will increase the difficulty of post-disaster recovery and increase the extent of damage to life and property [8].

Therefore, in response to extreme climate change, the goal of this study is to develop the response to environment changes for sustainable life and industrial development through the adjustment between social economy and land use based on the principles of mitigation and adaptation [1]. As for the planning tools for land use control and development, this study gives priority to public life and property safety and re-reviews the rationality of catchment development in order to achieve the goal of land conservation and sustainable development [7].

\subsection{Background of Zengwen Reservoir Catchment and Disaster Damage}

\subsubsection{Land Use for the Catchment}

Zengwen Reservoir, located upstream of the Zengwun River, was completed in 1973 to regulate water for irrigation in the Chianan Plain, as well as for power generation, flood prevention and tourism. Its total capacity is 700 million cubic meters and water surface area is 17 square kilometers. Its catchment area is approximately 70,029 hectares. Its land consists of forest land, agricultural land, and construction land, each taking up about 53,761 hectares (76.77\%), 8928 hectares (12.75\%) and 376 hectares (0.54\%) respectively.

The Zengwen Reservoir catchment is located in middle-high altitude area, with the majority of slopes classified as steep. Changes in rainfall patterns over recent years, coupled with mismanagement over catchment land use and development, resulted in multiple landslides and collapses. In addition, water from the channel that flows into the catchment area often contains a lot of sediment and alluvium, which poses a serious threat to the reservoir's sustainable management. Therefore, non-engineering management [7] methods should be employed for adjustment and planning on catchment soil conservation and land use to ensure land conservation, stable water supply, and disaster prevention and mitigation.

\subsubsection{Damage Caused by Typhoon Morakot}

From August 6 to 10, 2009, central and southern Taiwan had been badly hit by the prolonged heavy rains induced by Typhoon Morakot, which left 699 dead or missing, 1622 houses damaged, 1.2 billion cubic meters of hillside debris collapsed, 30 meters of silt accumulated at sediment dams, 30 meters of silt accumulated at river valley and 76,535 hectares flooded in Taiwan [8] [9]. The rainfall at 24, 48 and 72 hours during the period hit record-breaking heights 1623, 2361 and 2748 millimeters respectively and the 24 and 48 hours of rainfalls also approached world-record amounts of 1825 and 2467 millimeters [10]. The region that witnessed the most rainfall was the Alishan in Chiayi County, which is the upstream catchment for Zengwen, Nanhua and Wushantou Reservoirs. Landslides in the catchment area brought a large amount of sand and earth to the reservoirs, seriously affecting the water supply in southern Taiwan.

According to the Water Resources Agency [11], the collapse rate of catchment before the typhoon was 1.43\%, and the number tripled to $5.23 \%$ after it, with a dramatic increase in collapse area to 2277 hectares. The Nanhua Reservoir is mainly on forest land (approximately 91\%); while the Zengwen Reservoir is on forest land (48\%), hillside (21\%), main street and general roads (24\%), resulting in significant increase in reservoir sedimentation rate, decrease in reservoir capacity, and thus water supply shortage.

\subsection{Upstream Catchment Governance Trend}

To ensure the sensitive nature of the upstream catchment aquatic environment and the reservoir operational 
functions, comprehensive storm water management serves as the core of mitigation strategies in this study, which sets up classification rules for land conservation, protection of water resources, and disaster prevention. This study aims to maintain the ecological environment [12] [13] and to ensure the safety of people's lives and property and water supply by restricting land use in the catchment area for living and industrial purposes. Its governance principles include [14]:

- Keeping the catchment and downstream rivers from pollution and the impoundment areas from destruction.

- Prohibiting or restricting development and utilization within certain range of potential disaster areas, considering environmentally sensitive features, and making appropriate adjustment to land classification according to the current development.

- Planning and controlling the land use for domestic and industrial purposes.

- Regulating and reviewing land use in accordance with the ecological planning principles of avoidance and minimization [7].

\section{Mitigation Strategies}

\subsection{Overall Land Use Mitigation}

The deterioration of the environment and occurrence of natural disasters in Taiwan over the last decade has highlighted the urgent need for integration between land conservation and national security. In response to global climate change and for environmental sustainability, at present, the government is actively promoting legislation on national land planning to act as the basis for land safety and conservation [1] [15] [16]. Under the concept of safety, sustainability, and coexistence, development in areas for resource conservation and of potential hazards should be limited [17] [8] according to the eco-planning concepts such as avoidance, minimization, and compensation [7] to reduce conflicts of land use and occurrence of disasters and to promote land resources and environmental sustainability.

The research framework is as shown in Figure 1. This study, using map overlay analysis [5] [6], assesses the spatial distribution of the most suitable land use patterns within the catchment through environmental sensitivity analysis and suitability analysis, and then explores the direction of land use classification review with overlay zoning after cross-checking and adjusting current land use against existing land use regulations in Table $\mathbf{1}$.

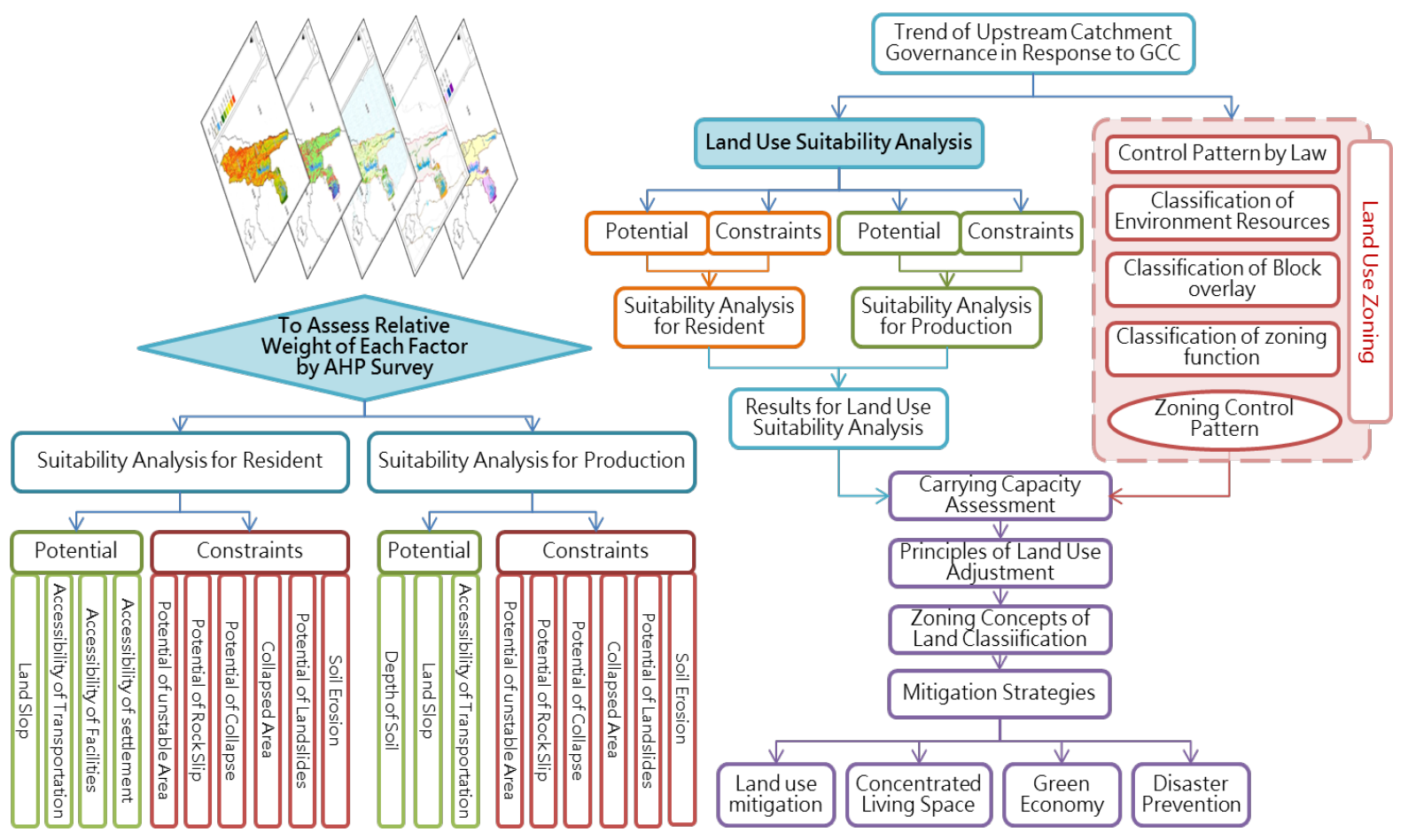

Figure 1. Research framework. 
Table 1. Land use adjustment for the Zengwen reservoir catchment with overlay zoning comparison with environmental sensitivity and suitability analysis.

\begin{tabular}{|c|c|c|c|c|c|c|c|c|}
\hline \multicolumn{2}{|c|}{$\begin{array}{l}\text { Environment } \\
\text { Sensitive Area }\end{array}$} & \multicolumn{2}{|c|}{$\begin{array}{l}\text { Results for Land Use } \\
\text { Suitability Analysis }\end{array}$} & \multicolumn{2}{|c|}{ Current Land Use } & \multicolumn{3}{|c|}{ Land Use after Adjustment } \\
\hline Item & $\begin{array}{l}\text { Area } \\
\text { (ha.) }\end{array}$ & Item & $\begin{array}{l}\text { Area } \\
\text { (ha.) }\end{array}$ & Item & $\begin{array}{l}\text { Area } \\
\text { (ha.) }\end{array}$ & Item & $\begin{array}{l}\text { Area } \\
\text { (ha.) }\end{array}$ & Regulating Principles \\
\hline \multirow{9}{*}{$\begin{array}{l}\text { Core } \\
\text { Area }\end{array}$} & \multirow{9}{*}{67,959} & \multirow{3}{*}{$\begin{array}{l}\text { Suitable for } \\
\text { Residential and } \\
\text { Agriculture }\end{array}$} & \multirow{3}{*}{2095} & Agriculture & 505 & \multirow{9}{*}{$\begin{array}{c}\text { National } \\
\text { Conservation } \\
\text { Area I }\end{array}$} & \multirow{9}{*}{67,959} & \multirow{9}{*}{$\begin{array}{l}\text { Prohibit Any } \\
\text { Development }\end{array}$} \\
\hline & & & & Residential & 31 & & & \\
\hline & & & & Others & 1560 & & & \\
\hline & & & & Agriculture & 634 & & & \\
\hline & & $\begin{array}{l}\text { Suitable for } \\
\text { Agriculture }\end{array}$ & 3367 & Residential & 50 & & & \\
\hline & & & & Others & 2683 & & & \\
\hline & & \multirow{3}{*}{ None of above } & \multirow{3}{*}{62,496} & Agriculture & 6460 & & & \\
\hline & & & & Residential & 349 & & & \\
\hline & & & & Others & 55,687 & & & \\
\hline \multirow{9}{*}{$\begin{array}{l}\text { Buffer } \\
\text { Area }\end{array}$} & \multirow{9}{*}{1049} & \multirow{3}{*}{$\begin{array}{l}\text { Suitable for } \\
\text { Residential and } \\
\text { Agriculture }\end{array}$} & \multirow{3}{*}{550} & Agriculture & 413 & Agricultural Area & 413 & Agriculture Use Only \\
\hline & & & & Residential & 17 & Urban-Rural Area & 17 & $\begin{array}{l}\text { Low Density } \\
\text { Development }\end{array}$ \\
\hline & & & & Others & 120 & $\begin{array}{c}\text { National } \\
\text { Conservation } \\
\text { Area II }\end{array}$ & 120 & $\begin{array}{l}\text { Conditional } \\
\text { Development }\end{array}$ \\
\hline & & \multirow{3}{*}{$\begin{array}{l}\text { Suitable for } \\
\text { Agriculture }\end{array}$} & \multirow{3}{*}{262} & Agriculture & 168 & \multirow{3}{*}{ Agricultural Area } & \multirow{3}{*}{179} & \multirow{3}{*}{ Agriculture Use Only } \\
\hline & & & & Residential & 11 & & & \\
\hline & & & & Others & 83 & & & \\
\hline & & \multirow{3}{*}{ None of above } & \multirow{3}{*}{237} & Agriculture & 110 & \multirow{3}{*}{$\begin{array}{l}\text { National } \\
\text { Conservation } \\
\text { Area II }\end{array}$} & \multirow{3}{*}{320} & \multirow{3}{*}{$\begin{array}{l}\text { Conditional } \\
\text { Development }\end{array}$} \\
\hline & & & & Residential & 5 & & & \\
\hline & & & & Others & 122 & & & \\
\hline \multirow{9}{*}{ None } & \multirow{9}{*}{1021} & \multirow{3}{*}{$\begin{array}{l}\text { Suitable for } \\
\text { Residential and } \\
\text { Agriculture }\end{array}$} & & Agriculture & 324 & $\begin{array}{c}\text { Agricultural Area } \\
\text { or Urban-Rural } \\
\text { Area }\end{array}$ & 324 & $\begin{array}{l}\text { Agriculture Use Only } \\
\text { or Low Density } \\
\text { Development }\end{array}$ \\
\hline & & & 584 & Residential & 31 & Urban-Rural Area & 31 & $\begin{array}{l}\text { Low Density } \\
\text { Development }\end{array}$ \\
\hline & & & & Others & 229 & $\begin{array}{c}\text { Agricultural Area } \\
\text { or Urban-Rural } \\
\text { Area }\end{array}$ & 229 & $\begin{array}{l}\text { Agriculture Use Only } \\
\text { or Low Density } \\
\text { Development }\end{array}$ \\
\hline & & & & Agriculture & 49 & & & \\
\hline & & $\begin{array}{l}\text { Suitable for } \\
\text { Agriculture }\end{array}$ & 181 & Residential & 12 & Agricultural Area & 181 & Agriculture Use Only \\
\hline & & & & Others & 120 & & & \\
\hline & & & & Agriculture & 85 & & & \\
\hline & & None of above & 257 & Residential & 18 & Conservation & 256 & $\begin{array}{l}\text { Conditional } \\
\text { Development }\end{array}$ \\
\hline & & & & Others & 153 & 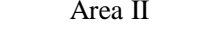 & & \\
\hline
\end{tabular}

Source: Compiled by the researcher.

\subsection{Limited Concentrated Land Use for Living Space}

Limited concentrated land use for living space to slow the impact of extreme weather, existing communities and settlements in the catchment are scattered. Due to the effects of extreme climate in recent years, landslides induced by almost every heavy rainfall pose a serious threat to the residents living in remote areas, and also increase the public and private investment in emergency evacuation, relief, and rehabilitation year by year. If limited government resources can be pooled to achieve maximum efficiency in public infrastructure, it can im- 
prove the quality of life of the residents, and more importantly, increase the efficiency of emergency assistance and disaster response [17].

The objective of the plan for the settlements and other land use should be to promote sustainable environmental development and to ensure the safety of the hill tribes, and the implementation strategies related to land restoration should be put forward [18]. The present study reviews and controls the distribution of existing settlements through comparison between the results of land suitability analysis and the current settlement use. If a settlement is in the national conservation area or its use is against the provisions of relevant laws and regulations, its inhabitants must migrate to another area suitable for living in so as to reduce the occurrence of disasters and over-exploitation.

\subsection{Zero Impact on Economic Development to Shape the Green Economy Industry}

The production activities within the catchment area are dominated by agriculture and tourism [19]. However, the steep and fragile terrain makes it unsuitable for development, this study consider the environmental carrying capacity [4] [6] [7] to guide industrial restructuring and reduce environmental hazards within the catchment area. This study discusses overuse, misuse over-regulation for the different land use patterns within the catchment area through the analysis of land carrying capacity, suitability and vulnerability to assess the spatial distribution of optimal land-use pattern within the scope, and takes zero impact [12] as the land development principle to achieve sustainable industrial and environmental development.

\subsubsection{Mitigation Strategies for Agriculture}

The land use and planning in the catchment area are closely related to river water quality, downstream water safety, disaster prevention, and other functions, so efforts should be made against violations such as land overuse and misuse within the range to seek rational utilization of upstream land.

- Progressive policies for land overuse, misuse should be adopted to gradually return farmland to forest. Land suitable for farming should be designated for pastoral reserves for farmers.

- Regulate and control land conservation and utilization. Redevelop the control rules for the improper use of agricultural land and sensitive land, and adjust its zoning according to the overuse processing or relocation compensation method.

- Designate appropriate production space and improve dry farmland production environment, counsel local farmers to grow crops in line with regional characteristics in the range, promote agricultural land and water conservation measures where appropriate, emphasize the hillside conservation concept, plant trees, and strengthen forest water conservation to reduce soil erosion and stabilize water supply in the catchment area.

\subsubsection{Mitigation Strategies for Tourism}

Most tourism resources in the catchment area are raw natural resources, unique and fragile, and priority should be given to ecotourism based on low level development and sustainable management according to their properties. Create new features by integrating local characteristic industries to develop sustainable ecotourism and promote sustainable development and environmental conservation.

- Follow the land conservation goals and adjust to the self-sufficiency green economic development model that interacts with nature based on changes in natural environment and ecological resources.

- According to the needs of different tour groups and local characteristics, design thematic recreation tours and build a local food industry chain.

- In light of the principle of sustainable development, implement local featured tours and establish relevant regulatory rules to avoid the destruction of local environmental resources by foreign tourists.

- Define the maximum carrying capacities to avoid over-development and implement overall development and quota control through the combination of tourism resources, local industry and road network.

\subsection{Strengthen the Planning Strategies for Disaster Prevention and Refuge Space}

The common disasters induced by steep slopes in the catchment are mudslides and landslides. The terrain and environmental factors contribute to the lack of spacious escaping space, shelter, and a short escape route [17]. This study proposes to take local schools, libraries, churches, police and fire units, and medical facilities for disaster prevention and rescue and plan emergency shelters and rescue routes by integrating transport systems. 
- Disaster prevention network system: Take Provincial artery road No. 3 as the core route of the emergency access system, supplemented by county main road as aid delivery channels, industrial roads as fire exits, and agricultural roads as emergency evacuation passages, to construct the regional disaster prevention network system [20].

- Shelter: According to the time sequence of disasters and corresponding behaviors, the shelter is divided into four levels. According to regional distance, potential scope of the disaster, shelter, medical care, supplies (including helicopter landing ground), and fire and police strongholds, a living shelter is set up based on 3 to 6 villages under the principle of proximity, totaling 10, as the minimum unit for disaster prevention.

\section{Conclusion}

Post-disaster reconstruction is a long and complex project, which includes: implementation of special budget, home rebuilding, infrastructure construction, industrial reconstruction, and prolonged reconstruction. The mitigation of land use is the basis of post-disaster reconstruction. The mitigation strategies proposed by this study for the land use of Zengwen Reservoir and its catchment are: 1) National Conservation Area I, about 67,959 hectares, prohibited from development or maintaining the status quo and taking progressive policies to return land to forest; 2) National Conservation Area II, about 696 hectares, allowing licensed development or limited development depending on the conditions of environmentally sensitive; 3) Urban-rural Development Area, about 601 hectares, consisting of 553 hectares also in Agricultural Development Area, which suitable for agriculture use only or low density development and can be developed moderately without destroying original ecological environment and landscape resources; 4) Agricultural development area, about 773 hectares, maintained basically for agricultural use, and adjusted for other purposes by local governments as a result of special needs.

\section{Acknowledgements}

The authors express sincere thanks to reviewers and editors for their insightful comments and constructive suggestions to level up the quality of this paper. Furthermore, this study is a part of the research result on "The Rational Land Use Planning by Suitability Analysis and Land Use Adjustment within the Catchment of the Zengwen, Nanhua and Wushantou Reservoirs”, which was commissioned by the Construction and Planning Agency.

\section{References}

[1] National Development Council (2012) Guideline of National Adaption Policy for Global Climate Change.

[2] Lee, C.-M. and Chen, C.-C. (2010) Vulnerability Indicator: Building and Assessment in Taiwan. City and Planning, 37.

[3] Wu, J.-Y. and Huang, Y.-S. (2011) The Establishment of Vulnerability Evaluation Indexes: The Case of Shueili Township, Nantou, Taiwan. City and Planning, 38.

[4] Berke, P.R., Godschalk, D.R., Kaiser, E.J. and Rodriguez, D.A. (2006) Urban Land Use Planning. 5th Edition, University of Illinois Press.

[5] Maantay, J. and Ziegler, J. (2006) GIS for the Urban Environment. ESRI Press.

[6] McHarg, I.K. (1971) Design with Nature. Paperback Edition, Nature History Press.

[7] Daniels, T. and Daniels, K. (2003) The Environmental Planning Handbook: For Sustainable Communities and Regions. American Planning Association.

[8] Professional Advisory, Committee of Disaster Reduction, The Executive Yuan, Taiwan (2010) Issues Analysis and Policy Suggestions for Morakot Typhoon Disaster.

[9] National Science and Technology Center for Disaster Reduction (2010) Disaster Survey and Analysis of Morakot Typhoon.

[10] Chen, Z.C. (2010) Disaster of Morakot Typhoon, Morakot Post-Disaster Reconstruction Council, the Executive Yuan, Taiwan.

[11] Water Resource Agency, Ministry of Economic Affairs, Taiwan (2009) Storm Rainfalls Density and Flood Volume Analysis Report of Morakot Typhoon.

[12] Kuo, F.-Y. (2010) Adapting Land Use Policy in the Face of Climate Change: The Case of Coastal Areas in Taiwan. City and Planning, 37.

[13] Kuo, M. (2003) Green and Blue Network: The Theory and Practice of Sustainable Landscape Planning. James Pub- 
lisher.

[14] Salvesen, D. (1990) Wetlands: Mitigation and Regulating Development Impact. 2nd Edition, The Urban Land Institute.

[15] Bryson, J.M. and Einsweiler, R.C. (1988) Strategic Planning: Threat and Opportunities for Planners. Planner Press.

[16] Staton-Reinstein, R. (2003) Success Planning: A “How to” Guide for Strategic Planning. Tobsus Press.

[17] Lee, C.-L. (2009) Global Climate Change Impacts on the Spatial Pattern of Socio-Economic Metabolism and Land Use Change: SEMLUC Model Application. City and Planning, 36.

[18] Li, H.-C. and Yang, H.-H. (2012) Assessing and Applying Social Vulnerability Index of Slop-Land Disasters. City and Planning, 39.

[19] Richardson, H.W. (1977) The New Urban Economic and Alternatives. Pion Limited.

[20] Hart, D. (1976) Strategic Planning in London: The Rise and Fall of the Primary Road Network. Pergamon Press. 